\author{
Beata Sadowska* \\ Adam Lulek ${ }^{* *}$
}

\title{
LOGISTICS COSTS AND BALANCED SCORECARD IN BUSINESS MANAGEMENT
}

\begin{abstract}
Streszczenie
Tasks performed in the logistic system require a cost. Strict cost association to logistics systems allows them to be distinguished from the overall costs of the company. Logistics costs reflect the consumption of resources owned by the enterprise due to the planning, implementation and control associated with the movement of goods. The costs must be managed, accounted and controlled.

The purpose of this paper is to show the possibility of using the logistics costing for managing the enterprise and reducing costs and to providing some tools that can be used in this area.
\end{abstract}

Keywords: costs, the company, management, cost accounting, SKW

* Beata Sadowska, dr, University of Szczecin, WZiEU, e-mail: beatasadowska71@wp.pl.

** Adam Lulek, dr, University of Szczecin, WZiEU, e-mail: adam-lulek@wp.pl. 


\section{Introduction}

The challenges faced by companies in the modern economy and in the face of rapidly changing economic realities make managing stakeholders realize the need for a complex and multi-faceted information. It would enable them to make informed decisions, and be effectively implemented, bringing tangible economic benefits to the company.

In the face of changes taking place in the modern, globalized economy, the client requires that delivered products or services provided meet the demands for high quality, appropriate quantity, proper time and place of delivery and acceptable to the level of costs. The solution in this case is the use of assisted management methods widely understood logistics, constituting a system supporting procurement processes of production and sales.

Cost Accounting in the traditional sense is part of the registration system of accounting and includes processes of identifying costs, their measurement, cost accounting, unit cost calculation and presentation of costs. Logistics cost management is made possible by the use of information from the logistics cost accounting and the application of management accounting tools. It can be implemented in terms of the strategic and operational level.

The purpose of this study is to systematize logistics costs, present, how you can use the logistics cost accounting and business management to reduce costs and to provide some tools that can be used in this area (Balanced Scorecard). At the time of writing methods of induction, deduction, and direct observation has been used. By analyzing the information from the literature, collected through direct interviews and based on the experience of the authors, as practitioners, pointed out the relationship between the company and led to managing logistics costs account. On this basis, the conclusions have been drawn.

\section{The role and importance of management in the enterprise}

The aim of the organization is to achieve high efficiency, ie to ensure satisfaction and customer satisfaction and increasing productivity at minimal cost. Changes in markets related to the competition mean that companies today are looking for different solutions related to their own development and maintenance of the market. Achieving the goals of the organization is possible with the appropriate management of this organization. 
Management is the act of allocation of resources. It is also connected with formulation of objective and activity strategy, it is the management by planning, motivating and controlling. ${ }^{1}$ Managing is taking a direct impact on people or teams that regulate one system by another. Management and administration is a set of activities that include: planning, decision making, organization, leadership; and resources are directed to the company and executed with the intent of achieving specific goals of the organization.

It should force people to achieve the overarching objectives of the company. It's well organized, planned human activity. This move towards the goals of a well thought out, planned and consistent. Management would like to find answers to the questions:

1. What and why should they organize, plan, control?

2. How is and how it should be?

3. Why is this and is it good?

4. What works well and what needs to be improved?

5. How should it be to make it more efficient, more effective?

6. What instruments to use to improve the competitiveness and performance of the organization?

Business process management difficulty results from globalization and international cooperation partners in supply chains, cooperation, production and distribution, requiring global standardization of electronic data interchange and electronic methods of cooperation. ${ }^{2}$

These people are setting appropriate objectives reflecting the pursuit of desired states of the organization through the allocation of resources to effectively implement action programs throughout the organization and its components. ${ }^{3}$ Managing a business in today's economy is a challenge for managers who need to quickly react to changes, guided by high flexibility in operation and often take risks, resulting in accurate management decisions and the rational management of the company, which is the appropriate management of logistics activities of the company.

1 S. Niziński, J. Żurek, K. Ligier, 2011. Logistics for engineers. Warszawa: Wydawnictwo Komunikacji i Łączności, 151.

2 B. Śliwczyński, 2005. Management of business processes in the supply chain supported by the tools of electronic economy. LogForum 1, 1, 1 .

3 D.E. Schendel, K.J. Hatten, 1972. Business Policy on Strategic Management: A View for an Emerging Discipline. New York: Academy of Management Proceedings. 


\section{Objectives and tasks of logistics}

Logistics is historically well established and its origins are looking for in ancient times. It is planning and flows control of materials, people, energy and information. It's natural supply of resources; Logistics should make that energy, materials or goods are always available in the right place, time and at a reasonable cost. ${ }^{4}$ It is the planning, implementation and control of cost-effective, and efficient and effective movement of products, raw materials for the manufacture or sale and the relevant information from the starting point to the point of consumption in order to best meet the needs of the customer.

Logistics, and especially its' competence may be among the "areas", which can significantly affect and shape changes in the system of business management. The purpose of its' activities is the management of the company to achieve the desired effects and economic market. ${ }^{5}$ The primary purpose of which is achieved by using the logistics company is the availability. This objective is associated with the principle 7R, which is presented in Figure 1.

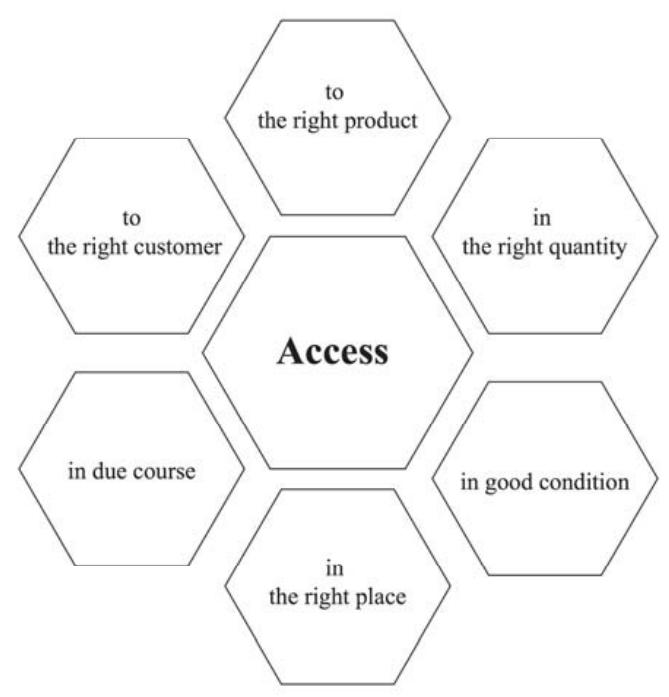

Figure 1. The rule of $7 \mathrm{R}$

Source: own study.

4 M. Biernacki, R. Kowalak, 2010. Logistics cost accounting in business management. Wrocław: Wydawnictwo Uniwersytetu Ekonomicznego we Wrocławiu, 9, 17.

5 R. Matwiejczuk, 2012. The influence of logistics potentials on business management. LogForum 8 (3), 201-216, www.logforum.net/vol8/issue3/no3 [27.12.2014]. 
Another objective of logistics is to achieve the optimal flow of communication and coordination of materials, raw materials, goods, products and activities related to their storage and transport. Tasks related to this concern the improvement of the management process flow and storage of products, the construction of logistics chains, the subordination of operations and logistics processes customer expectations, increasing the efficiency of the flow of goods that affect the flow of cost savings and process costs and logistics activities. ${ }^{6}$ Taking into account all aspects of modern business of the undertaking, the tasks should also be credited with logistics transportation, repair, order processing, inventory control, which is presented in Figure 2.

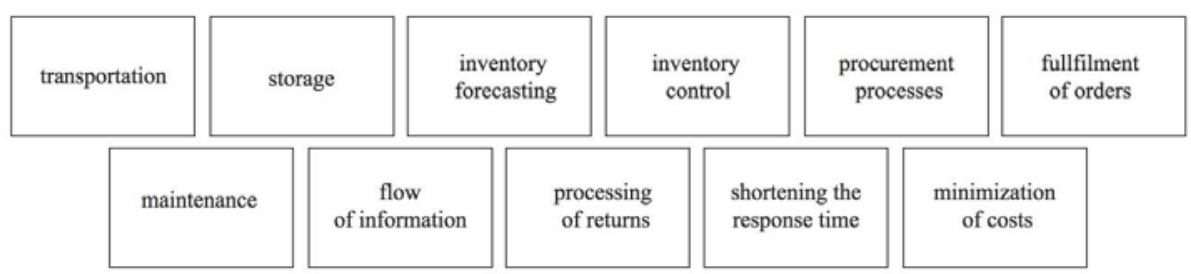

Figure 2. Tasks of logistics

Source: own study.

The current time is a global competition on the markets, the increase in customer requirements, broad access to new technologies and information. These facts meant that companies are looking for new management methods and tools, including the use of the principles and methods of operation of modern logistics. Selected targets and tasks (functions) of logistics are presented in table 1.

Objectives and tasks of logistics in conjunction with the efficiency of logistics processes become more and more important nowadays. Actions lead to the rationalization of its' business processes in the formation of the level and quality of services, a system of customer value and determinating the level of logistics costs.

6 M. Biernacki, R. Kowalak, 2010. Logistics cost accounting in business management. Wrocław: Wydawnictwo Uniwersytetu Ekonomicznego we Wrocławiu, 17, 101. 
Table 1. Objectives and tasks of logistics

\begin{tabular}{|c|c|c|}
\hline \multicolumn{3}{|c|}{ The basic tasks of logistics } \\
\hline in production & in supply & in the area of distribution \\
\hline $\begin{array}{l}\text { - planning processes of storage } \\
\text { and the transporting } \\
\text { - planning the structure and } \\
\text { production systems }\end{array}$ & $\begin{array}{l}\text { - planning storage sites } \\
\text { - planning of materials } \\
\text { and raw materials }\end{array}$ & $\begin{array}{l}\text { - planning warehouse locations } \\
\text { - planning distribution structure } \\
\text { - external logistics planning }\end{array}$ \\
\hline $\begin{array}{l}\text { - production control } \\
\text { - control the use of personnel } \\
\text { and technical equipment } \\
\text { - exchange of information }\end{array}$ & $\begin{array}{l}- \text { planning of delivery } \\
\text { dates, type of packag- } \\
\text { ing } \\
\text { - control and monitoring } \\
\text { of the reception and } \\
\text { storage of materials } \\
\end{array}$ & $\begin{array}{l}- \text { planning the use of means } \\
\text { of transport } \\
- \text { scheduling to deliver the goods } \\
- \text { finished goods inventory con- } \\
\text { trol } \\
\text { - packing of goods }\end{array}$ \\
\hline $\begin{array}{l}\text { - determining the needs of the } \\
\text { production } \\
\text { - determine the load of ma- } \\
\text { chines } \\
\text { - planning the production } \\
\text { batch }\end{array}$ & $\begin{array}{l}\text { - evaluation and selection } \\
\text { of suppliers } \\
\text { - determine the size } \\
\text { of the supply }\end{array}$ & $\begin{array}{l}\text { - provision of programs for sale, } \\
\text { transport, storage }\end{array}$ \\
\hline
\end{tabular}

Source: own study.

\section{Systematics of logistics costs}

The cost of overall consumption is expressed in terms of value of production factors, assigned to the period and bringing economic effect. The costs in terms of logistics costs are a special category. These costs in an organization are the sum of expenses associated with ongoing logistics functions, eg. shopping, storage, transport, distribution, customer service, information flows. Considering the most common definition of "logistics costs" costs are treated as general expenses related to logistics processes that are carried out in the company (ie: depreciation, maintenance and operation of fixed assets, organization and management of the physical flow and storage of materials, semi-finished products (goods or products), data management and data flow, staff salaries and related costs, liabilities and external services, such as transport, maintenance). Taking into account the above, it should be noted that in relation to the cost of the two aspects are of particular interest: the identification and optimization of costs. ${ }^{7}$

7 A. Wartecki, 2008. New approach to logistics costs of a freight forwarders' company. $\operatorname{LogForum~4,~3,~} 3$. 
Logistics costs should include: ${ }^{8}$

- Planned logistics costs, which are costs: transportation supply, manufacture, maintenance and aging inventory, warehouse and transport economy, interest rates on loans, information, etc.),

- Unscheduled logistics costs concerning, eg. maintenance of surplus stocks and loans (storage, handling, and the interest on the loan), improper transport costs (uneconomic party supplies violations geography), etc.,

- Losses due to defective materials management, among others, downtime for lack of material, rejects culpable wrong material, penalties for improper delivery.

Due to the source logistics cost production phases can also highlight the following distribution logistics costs: ${ }^{9}$

- Costs of obtaining materials from suppliers,

- Transport costs and external-house,

- Costs of production planning,

- Storage costs of intermediate products, goods, materials and waste,

- The cost of the transfer of finished goods to customers.

According to P. Blaik (2001) the structure of the total cost of logistics can be described by the following formula:

$$
K L=K_{Z p}+K_{S p}+K_{M}+K_{T}+K_{K z}+K_{P p}+K_{P i}+K_{O}+K_{N s}
$$

where:

$K_{Z p}-$ the cost of shaping, planning, controls, material flows and goods (cost flow management),

$K_{S p}-$ logistics costs, production planning and control, and execution of orders,

$K_{M}-$ storage costs,

$K_{T}-$ transport costs,

$K_{K z}$ - shaping inventory costs,

$K_{P p}-$ costs of preparing the product for shipment and sale (packaging, handling),

$K_{P i}-$ the costs of forming and development of information flows orders,

8 Twaróg J., 2003. The costs of logistics enterprises. Poznań: Biblioteka Logistyka, $26-27$.

Ibidem 
$K_{O} \quad-$ maintenance costs, logistics,

$K_{N} \quad-$ disability costs, excessive expenditures, the additional cost and passed on to market partners and lost profits.

Complex formula by Blaik of logistics costs include the costs associated with logistics functions. Each of these areas is reflected in the formula and any significant impact on the total value of logistics costs. These divisions do not exhaust the catalog of the concept to include the costs of logistics. Most often in the theory and practice of management in the enterprise logistics costs are used because of the divisions: Logistics segments and the phase flow of materials, products and goods, which is presented in Figure 3.
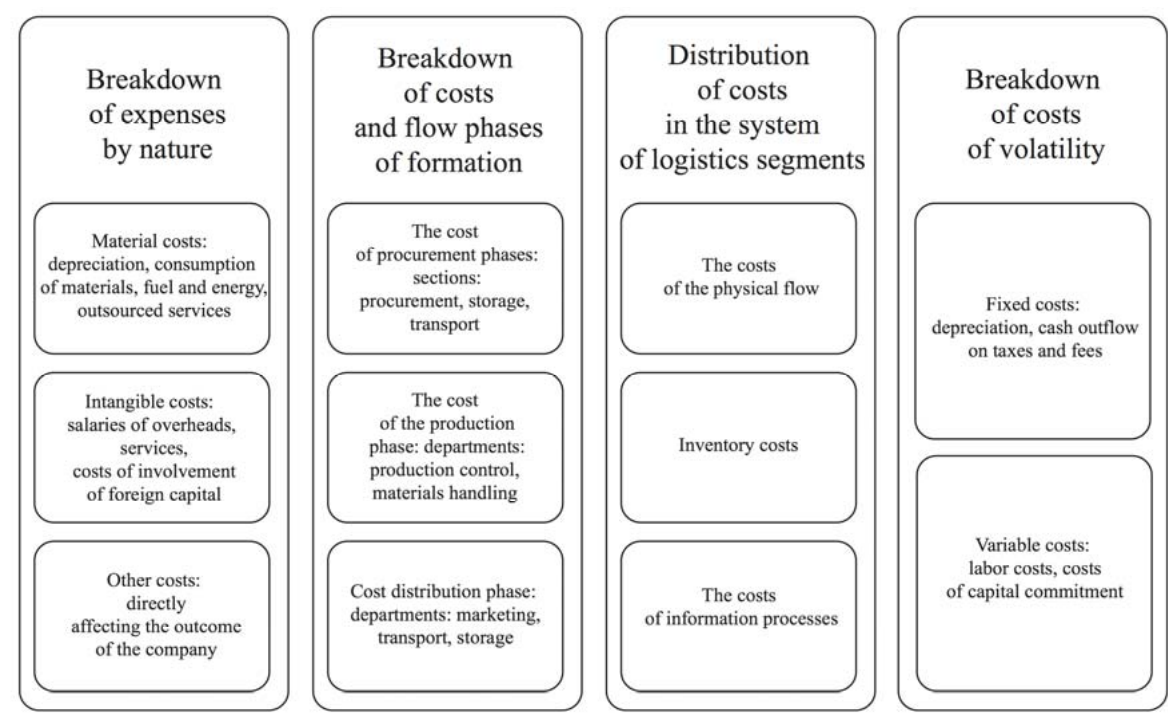

Figure 3. Allocation of costs due to: the segments logistics and material flow phase, products and goods

Source: J. Twaróg, 2003. Koszty logistyki przedsiębiorstw. Poznań: Instytut Logistyki i Magazynowania EAN Polska.

In addition to these cost categories it is possible to also point the opportunity costs and the costs of acquiring, operating and maintaining the client. In modern enterprises, functioning in an environment shaped the processes of globalization, the issue of customer acquisition and retention is becoming increasingly important, as it is often believed to be the sources of business success of enterprises. 
In the face of changes taking place in the modern, globalized economy, the client requires that delivered products or services provided meet the demands for high quality, appropriate quantity, proper time and place of delivery and acceptable to the level of costs. The solution in this case is the use of cost management methods supported the wider logistics, constituting a system supporting procurement processes of production and sales.

\section{Logistics cost management in the enterprise}

Logistics cost management is essential to the overall operating costs of the business. This is due to the increasing share of indirect costs in the total operating costs of enterprises. This process is made possible by the use of information from the logistics cost accounting and the application of accounting tools, such as Balanced Scorecard and costing activities aimed at reducing the cost of business.

Balanced Scorecard is a system for measuring the efficiency and effectiveness of the entity in a number of perspectives, which allows to translate the vision, mission and strategy into tangible goals. This makes it possible to link the daily activities and operations of all departments / papers of the organization and employees with the strategic objectives of the company. Scorecard measures to make business in a sustainable way, (it may contribute to reducing the cost) watching them from four perspectives:

1. Customer perspective identifies the sources of the success of the plant, which are the market position and customer satisfaction (How should we look in the eyes of customers, in order to achieve its mission and vision? How to implement the tasks and meet the expectations of our customers, while controlling operating costs? Does the company provide services, customers expect and owners?

2. The internal processes perspective measured characteristics of processes within the organization (On what processes should we be particularly focused to meet our customers' expectations and what the company can be changed to provide a better service? How to improve communication within the organization? Do they understand the mission and vision of the company? are employees initiators of changes in the organization?). 
3. The perspective of development measures a company's ability to change and further growth (How do I maintain readiness for innovation and change in the organization to carry out its mission and vision? Does the company provide training for workers to be able to continually improve? Is the means for new investments? Is creating new investment?).

4. The financial perspective - financial goals are a reference point for the goals and measures formulated in the context of other scorecard perspectives (Does the company's financial rational? Is it financially independent? To what extent is the organization's activity is dependent on financing the operations of decision-makers? Does the company generates profit or loss at the end of the year?).

Examples of goals, areas and measures used in the Strategic Scorecard for the company are presented in Table 2 .

Table 2. Examples of measures used in the Strategic Scorecard

\begin{tabular}{|c|c|c|c|}
\hline Perspective & Business Objectives & Examples of measures & Reducing costs by: \\
\hline 1 & 2 & 3 & 4 \\
\hline Customer & $\begin{array}{l}\text { full availability of services, } \\
\text { access to services and products } \\
\text { in a timely manner } \\
\text { offering services and products } \\
\text { of the highest quality products } \\
\text { minimize the time customer } \\
\text { service } \\
\text { - professional customer service } \\
\text { - strimize business risk } \\
\text { of the companing-customer } \\
\text { increasing the level of cus- } \\
\text { tomer satisfaction }\end{array}$ & $\begin{array}{l}\text { - number of items delivered } \\
\text { on time } \\
\text { the number of damaged } \\
\text { items in transit } \\
\text { delivery time of products } \\
\text { to customers }\end{array}$ & $\begin{array}{l}\text { delivery of goods, pro- } \\
\text { ducts, products on time } \\
\text { the use of activity based } \\
\text { costing and enterprise } \\
\text { division of responsibility } \\
\text { centers } \\
\text { - outsourcing of transpor- } \\
\text { tation and other tasks } \\
\text { outsourced } \\
\text { - increasing fidelity terms } \\
\text { and quantities }\end{array}$ \\
\hline Financial & $\begin{array}{l}\text { - effective use of financial } \\
\text { resources } \\
\text { collaboration with partners } \\
\text { and providers of outsourced } \\
\text { services } \\
\text { the implementation of a finan- } \\
\text { cial plan, make some adjust- } \\
\text { ments and amendments to the } \\
\text { Plan over the financial year } \\
\text { task scheduling }\end{array}$ & $\begin{array}{l}\text { - turnover ratio and the } \\
\text { inventory cycle } \\
\text { - turnover rates and the cycle } \\
\text { of materials and finished } \\
\text { products } \\
\text { - transportation costs } \\
\text { storage costs }\end{array}$ & $\begin{array}{l}\text { minimizing the cost } \\
\text { of capital } \\
\text { - simplify the organizational } \\
\text { structure } \\
\text { controlling the use } \\
\text { of tools }\end{array}$ \\
\hline
\end{tabular}




\begin{tabular}{|c|c|c|c|}
\hline 1 & 2 & 3 & 4 \\
\hline $\begin{array}{c}\text { Internal } \\
\text { processes }\end{array}$ & $\begin{array}{l}\text { - improve the flow of informa- } \\
\text { tion } \\
\text { - building trust within the orga- } \\
\text { nization } \\
\text { - creating favorable conditions } \\
\text { of work } \\
\text { - deviations and processes to } \\
\text { eliminate unnecessary } \\
\text { - improving communication } \\
\text { processes } \\
\text { implementation of new proce- } \\
\text { dures and internal law }\end{array}$ & $\begin{array}{l}\text { - time delivery of raw mate- } \\
\text { rials from the warehouse to } \\
\text { the production department } \\
\text { - time of transfer of finished } \\
\text { goods from production to } \\
\text { the finished goods ware- } \\
\text { house } \\
\text { - the number of quality } \\
\text { control } \\
\text { - time control of raw ma- } \\
\text { terials } \\
\text { - level of capacity utilization } \\
\text { forklift }\end{array}$ & $\begin{array}{l}\text { - inventory optimization } \\
\text { - educing the time of the } \\
\text { flow of materials and } \\
\text { - acceleration of orders } \\
\text { time } \\
\text { - the creation of cost and } \\
\text { profit centers }\end{array}$ \\
\hline $\begin{array}{l}\text { Develop- } \\
\text { ment }\end{array}$ & $\begin{array}{l}\text { - increase the quality of cus- } \\
\text { tomer service } \\
\text { - raising the qualifications } \\
\text { of employees } \\
\text { - creating conditions for self- } \\
\text { education } \\
\text { - loyalty and commitment } \\
\text { of employees } \\
\text { - flexibility of the organization } \\
\text { - integration objectives with } \\
\text { personal goals plant workers }\end{array}$ & $\begin{array}{l}\text { - } \text { number of training courses } \\
\text { attended by employees } \\
\text { - the percentage of people } \\
\text { with higher education } \\
\text { - staff turnover rate } \\
\text { - number of innovations } \\
\text { implemented and the num- } \\
\text { ber of innovating } \\
\text { - the rate of improvement } \\
\text { of organizational and } \\
\text { technical } \\
\text { - employee productivity } \\
\text { - involvement of employees } \\
\text { - self-education }\end{array}$ & $\begin{array}{l}\text { - the use of electronic } \\
\text { computer technology } \\
\text { - close coordination and } \\
\text { greater flexibility } \\
\text { - promoting awareness } \\
\text { of the importance } \\
\text { of costs } \\
\text { - sensitize employees to } \\
\text { the negative phenomena } \\
\text { - effects control }\end{array}$ \\
\hline
\end{tabular}

Source: own study based on: M. Biernacki, R. Kowalak, 2010. Rachunek kosztów logistyki w zarządzaniu przedsiębiorstwem. Wrocław: Wydawnictwo Uniwersytetu Ekonomicznego we Wrocławiu, 2010; B. Śliwczyński, 2005. Controlling operacyjny tańcucha dostaw brakujacym ogniwem Strategicznej Karty Wyników. LogForum 1, 2, 7, www.logforum. net/vol1/issue2/no1 [2.12.2014].

Other tools connected with logistics costing supporting company management and reducing the cost of the company's activities include: activity based costing, budgeting, benchmarks, variance analysis and reporting. Due to the limited volume of the development these issues will not be discussed in detail. They may be a subject to further consideration of the costs and management.

\section{Summation}

On the basis of systematic analysis of the logistics costs, logistics cost accounting, business management and reducing operating costs, the following conclusions appear:

1. The purpose of any organization is to achieve high efficiency, ensuring customer satisfaction, increase productivity, and performance at minimum cost. 
2. Cost of logistics, is a collection of information about the cost of logistics in the company.

3. Presented in the development of the chosen solutions affect the improvement of enterprise management, improve the quality of service delivery, lower operating costs and efficient use of resources.

4. Balanced Scorecard:

1) may be used to communicate the purpose of individual cells organizational and staff with the vision and mission of the unit,

2) determines to make a systematic analysis of the indicator, and thus generate additional information for the management,

3) allows you to create an optimal incentive system,

4) generates lower operating costs and achieves higher revenues by economic unit,

5) a positive effect on communication with internal and external customers plant,

6) ensures the timely implementation of tasks and tasks involved in the implementation of all employees of the plant.

5. Reduction of logistics costs can be achieved by taking the following actions:

1) optimizing inventory, achieved by determining the optimum relation to the storage area maintenance costs, so as to ensure the liquidity of storage at the lowest possible cost of storage (using information from the logistics cost accounting),

2) reduce the time flow of materials, products and goods, achieved by taking action optimization (also on the basis of information from the bill of costs), whose purpose is to deliver the goods on time and avoid shortages in every phase of the business, from sourcing to production to distribution,

3) shorter lead-times, through a review of activities in the area of logistics and analysis of their costs (based on information from the account logistics costs) and the choice of optimal solutions (eg. logistics outsourcing rather than its own, the effective flow of information, etc.).

6. The factors determining the use of these solutions in practice is to gain acceptance for the process of managerial staff and employees of the entity. This follows from the fact that it is these people are responsible for implementing and functioning of the whole system, and the level of their knowledge and awareness of activities undertaken directly translates into the 
results achieved. You can form the view that the success and failure in the management of logistics costs have their source in the human factor, it should be, so try to raise the level of awareness and gaining acceptance for the process of those responsible for its implementation and operation.

\section{Bibliography}

Biernacki M., Kowalak R., 2010. Logistics cost accounting in business management. Wrocław: Wydawnictwo Uniwersytetu Ekonomicznego we Wrocławiu, 9, 17,101.

Blaik P., 2001. Logistics. Warszawa: Państwowe Wydawnictwo Ekonomiczne, 304.

Matwiejczuk R., 2012. The influence of logistics potentials on business management. LogForum 8 (3), 201-216, www.logforum.net/vol8/issue3/no3 [27.12.2014].

Niziński S., Żurek J., Ligier K., 2011. Logistics for engineers. Warszawa: Wydawnictwo Komunikacji i Łączności, 151.

Schendel D.E., Hatten K.J., 1972. Business Policy on Strategic Management: A View for an Emerging Discipline. New York: Academy of Management Proceedings.

Śliwczyński B., 2005. Management of business processes in the supply chain supported by the tools of electronic economy. $\operatorname{LogForum~} 1,1,1$.

Śliwczyński B., 2011. Operational controlling - a tool of translating strategy into action. LogForum 7, 1, 5 .

Twaróg J., 2003. The costs of logistics enterprises. Poznań: Biblioteka Logistyka, $26-27$.

Wartecki A., 2008. New approach to logistics costs of a freight forwarders' company. LogForum 4, 3, 3, www.logforum.net/vol4/issue3/no3 [27.12.2014].

www.logforum.net/voll/issue1/no1 [27.12.2014].

www.logforum.net/vol7/issue1/no5 [28.12.2014]. 


\section{KOSZTY LOGISTYKI I STRATEGICZNA KARTA WYNIKÓW W ZARZĄDZANIU PRZEDSIĘBIORSTWEM}

\section{Streszczenie}

Wyzwania, przed którymi stają przedsiębiorstwa w nowoczesnej gospodarce i w obliczu dynamicznie zmieniającej się rzeczywistości gospodarczej, powodują, iż zarządzający podmiotami coraz częściej uświadamiają sobie konieczność posiadania złożonych i wieloaspektowych informacji umożliwiających im podejmowanie trafnych decyzji, które byłyby skutecznie realizowane, przynosząc przedsiębiorstwu wymierne korzyści ekonomiczne. W obliczu zmian zachodzących we współczesnej, zglobalizowanej gospodarce klient wymaga, aby dostarczane mu produkty czy świadczone usługi spełniały wymagania dotyczące wysokiej jakości, odpowiedniej ilości, właściwego czasu i miejsca dostarczenia lub wykonania oraz akceptowalnego dla niego poziomu kosztów. Rozwiązaniem w tym przypadku jest stosowanie metod zarządzania wspomaganych szeroko rozumianą logistyką, stanowiącą system wspierający procesy zaopatrzenia produkcji i zbytu.

Rachunek kosztów w tradycyjnym ujęciu stanowi część systemu ewidencyjnego rachunkowości i obejmuje procesy: identyfikacji kosztów, ich pomiaru, ewidencji kosztów, rozliczania kosztów, kalkulacji kosztów jednostkowych oraz prezentacji informacji o kosztach. Zarządzanie kosztami logistyki jest możliwe dzięki wykorzystaniu informacji pochodzących z rachunku kosztów logistyki oraz zastosowania narzędzi rachunkowości zarządczej. Może być ono realizowane w ujęciu strategicznym oraz operacyjnym.

Celem niniejszego opracowania było zaprezentowanie, jak można wykorzystać rachunek kosztów logistyki do zarządzania przedsiębiorstwem i redukcji kosztów, oraz przedstawienie wybranych instrumentów możliwych do zastosowania w tym obszarze.

Słowa kluczowe: koszty, przedsiębiorstwo, zarządzanie, rachunek kosztów, SKW 